\title{
Agroforestry systems and their effects on the dynamics of solar radiation and soybean yield
}

\author{
Jaqueline Sgarbossa ${ }^{1 *}$, Felipe Schwerz', Elvis Felipe Elli², \\ Liliane Bárbara Tibolla', Denise Schmidt', Braulio Otomar Caron' \\ 'Federal University of Santa Maria, Frederico Westphalen, Brazil \\ 2University of São Paulo, Piracicaba, Brazil \\ *Corresponding author, e-mail: sgarbossajs@yahoo.com
}

\begin{abstract}
Agroforestry systems have been highlighted in the agricultural environment as an alternative form of sustainable production to meet the growing demand for food and energy with less environmental impact. Thus, the aim of this study was to evaluate the effect of different forest species on the dynamics of solar radiation and the productive response of soybean grown in agroforestry systems. Two field experiments were carried out in the city of Frederico Westphalen - Rio Grande do Sul, Brazil. In order to reach the aim of this study, the solar radiation transmissivity and the productive performance of soybean were evaluated. Productivity followed the same tendency as solar radiation transmissivity; in an agricultural year, the species with the higher incidence of solar radiation to the understory presented the best yield. The forest species Schizolobium parayba, Peltophorum dubium and Parapiptadenia rigida were used as they present the potential to compose the agroforestry systems; their canopy structure and leaf architecture provide greater availability of solar radiation in the subforest. The interception of solar radiation by the forest component of more than $50 \%$ significantly reduces soybean yield in agroforestry systems, requiring silvicultural practices that promote the availability of solar radiation in the understory.
\end{abstract}

Keywords: crop systems, solar radiation transmissivity, sustainable production, tree pruning, yield traits

\section{Introduction}

The rapid changes occurring in the agricultural environment associated with increasing population demand for energy and food has increased the need for the development of more sustainable agriculture (Godfray et al., 2010). In response, agroforestry systems have emerged as a consistent and promising alternative to maximizing the production system, diluting the costs of implementation agroforestry, increasing carbon sequestration and nutrient cycling, and reconstituting the chemical and biological properties of soil through intercropping between agricultural and forestry species (Tracy \& Zhang, 2008; Salton et al., 2013).
Agroforestry systems consist of integrated land use for forestry and agricultural purposes, exploring plant resources in a rational way through activities with lower environmental impact in relation to systems, where only one culture is conducted (Brooker et al., 2014). Soybean (Glycine max) stands out in the world agricultural scenario for being one of the main sources of protein and vegetable oil, widely used in food and feed. Therefore, the use of culture in intercropping systems, as in the case of agroforestry systems, emerges as an alternative for more sustainable production through the intensification of land use, insertion of marginalized areas into the production system and reduction in 
the exploitation of new areas, thus contributing to the maintenance of biomes.

Simultaneous growth and development of different species in the same production area occurs In consortium systems, thus promoting changes in plants' community interactions. There is a continuous increase in height, canopy projection and leaf area index In places where forest species are present, which changes the distribution of natural resources over time(Müller et al., 2014), especially solar radiation (Elli et al., 2016).

According to Beer's law, the flux of solar radiation decreases exponentially as it enters a homogeneous environment. When it reaches the canopy, solar radiation may undergo some quantitative and qualitative changes (Caron et al., 2012), and can be reflected, absorbed or transmitted, depending on the angle of incidence of the sun's rays, architecture of the canopy and leaves' geometry (Behling et al., 2016).

The interception of solar radiation by forest species above 39\% (Bosi et al., 2014) can interfere with growth and development of plants grown in the understory. Therefore, silvicultural practices such as canopy driving and tree pruning are indispensable when the aim is to increase the transmissivity of solar radiation by the understory and achieve balance between agricultural and forestry farming in order to meet the demand for energy and food.

Considering the importance of alternative production systems and the scarcity of information about them, the present study had as an objective to evaluate the effect of different agroforestry systems and tree pruning on the dynamics of solar radiation and soybean yield.

\section{Materials and methods}

The data for carrying out the study were obtained in field experiments in Frederico Westphalen - Rio Grande do Sul, under geographic coordinates $27^{\circ} 23^{\prime} 48$ ' S, 5325'45 ", $461.3 \mathrm{~m}$ of altitude. The climate of the region is type Cfa, according to Köppen classification, where temperatures from the cooler three months are contained in the range of -3 to 18 ${ }^{\circ} \mathrm{C}$, with average air temperature in the hottest month greater than or equal to $22{ }^{\circ} \mathrm{C}$, and annual accumulated rainfall between 1,200 and $2,040 \mathrm{~mm}$ occurring in all months of the year (Alvares et al., 2013). The soil of the area presents the physical-chemical characteristics described in Table 1, with fertilisation based on soil analysis following recommendations for the soybean crop.

Table 1. Physical-chemical composition of the experimental area in the two crop years (2013/2014 and 2014/2015). Southern Brazil.

\begin{tabular}{|c|c|c|c|c|c|c|c|c|}
\hline $\begin{array}{l}\text { Crop } \\
\text { year }\end{array}$ & $\begin{array}{c}\mathrm{pH} \\
\left(\mathrm{H}_{2} \mathrm{O}\right)\end{array}$ & $\mathrm{P}(\mathrm{mg} / \mathrm{L})$ & $\mathrm{K}(\mathrm{mg} / \mathrm{L})$ & $\mathrm{Ca}(\mathrm{cmolc} / \mathrm{L})$ & $\mathrm{Mg}(\mathrm{cmolc} / \mathrm{L})$ & CTC (cmolc/L) & $\vee(\%)$ & $\mathrm{MO}(\%)$ \\
\hline $2013 / 14$ & 5.25 & 4.45 & 68.5 & 10.65 & 2.8 & 18.4 & 74.3 & 3.35 \\
\hline $2014 / 15$ & 5.2 & 4.5 & 56.5 & 8.9 & 1.8 & 16.75 & 64.8 & 3.45 \\
\hline
\end{tabular}

The experimental design was a randomized block design, arranged in a factorial scheme $2 \times 4 \times 2$, with two cropping systems, consortium and monoculture of soybean (Mono.), four forest species Peltophorum dubium (Spr.) Taubert) (P. dub.), Eucalyptus urophylla S.T. Blake x Eucalyptus grandis Hill ex Maiden (Euc.), Parapiptadenia rígida (P. rig.) and Schizolobium parahyba (S. par.) and two crop years of 2013/2014 and 2014/2015.

The planting of forest species was carried out in the field in September 2007, where it proceeded by plowing and grading what would become the experimental area, followed by manual planting of seedlings. During the experimental period the trees were between 9 and 10 years old in crop years 2013/2014 and 2014/2015, respectively. The allometric characteristics are shown in Table 2. Forest species were distributed in spacing of $6 \times 1.5 \mathrm{~m}$, that is, $6 \mathrm{~m}$ between lines, and $1.5 \mathrm{~m}$ between plants on the line with lines laid in in the east-west direction.

The soybean was sown in the month of 
November in both crop years, with spacing of $0.45 \mathrm{~m}$ between lines, resulting in 250,000 $\mathrm{ha}^{-1}$ plants. In the two crop years the cultivar Nidera A
RG 6411 was used, characterized by presenting determined growth habit, early cycle and height of plant.

Table 2. Description of the mean allometric characteristics of plant height, diameter at breast height (DBH) and mean diameter of canopy (D.Canopy) of forest species. Southern Brazil.

\begin{tabular}{ccccc}
\hline Crop Year & Species & Height $(\mathrm{m})$ & D.Canopy $(\mathrm{m})$ & DBH $(\mathrm{cm})$ \\
\hline $2013 / 2014$ & S. parayba & 9.05 & 3.75 & 49.46 \\
$2014 / 2015$ & S. parayba & 11.23 & 4.11 & 52.94 \\
$2013 / 2014$ & P. dubium & 7.63 & 4.01 & 39.07 \\
$2014 / 2015$ & P. dubium & 9.40 & 4.84 & 47.12 \\
$2013 / 2014$ & P. rigida & 10,00 & 5.10 & 37.35 \\
$2014 / 2015$ & P. rigida & 10.51 & 5.27 & 43.20 \\
$2013 / 2014$ & Eucalyptus & 21.85 & 4.12 & 66.25 \\
$2014 / 2015$ & Eucalyptus & 23.15 & 4.23 & 87.55 \\
\hline
\end{tabular}

After sowing the soybean, the plots were delineated in order to be two meters long and distributed in different points of the understory of each experimental unit. These points were selected with the objective of representing the microclimatic conditions formed under the canopy of each forest species. The arrangement of the tree components, soybean and evaluation points are shown in Figure 1.

To determine the transmissivity of solar radiation, incident global radiation was measured throughout the production cycle of soybean with a pyranometer coupled to a datalogger (LICOR 1400), measuring from 10:00 am until 12:00 noon. The sampling points within each plot were systematically established in three different directions, one located within the line (1), another between each line (2) and the third at a $45^{\circ}$ angle between points 1 and 2 .

From the data obtained the transmissivity of the radiation was calculated for each species, through the following equation:

$$
T=(R n / R t) \times 100
$$

Where: T: rate of transmissivity (\%); Rn: solar radiation incident within the undestory $\left(\mathrm{W} \mathrm{m}^{-2}\right)$; Rt: solar radiation incident above the canopy of trees $\left(\mathrm{W} \mathrm{m}^{-2}\right)$.

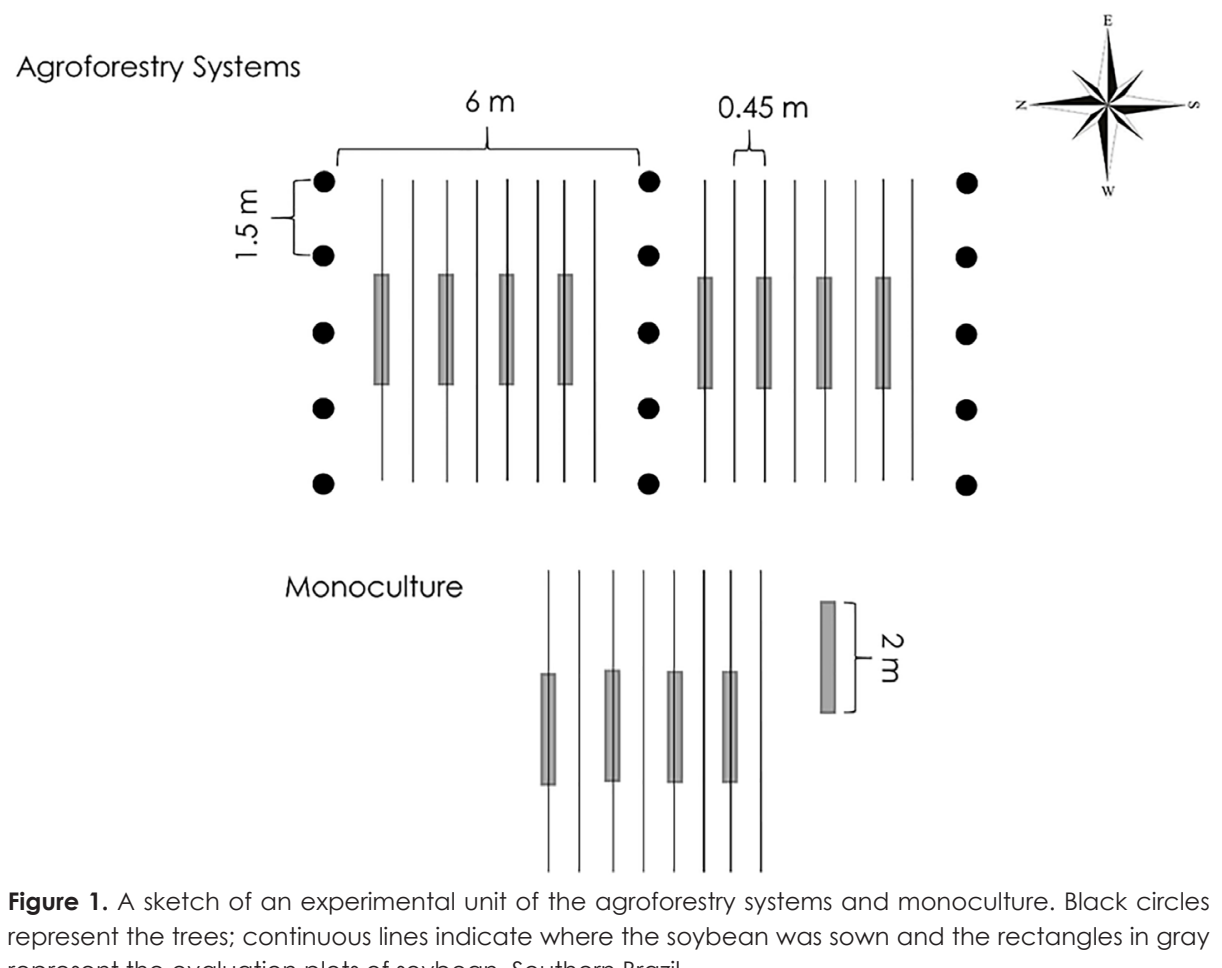
represent the trees; continuous lines indicate where the soybean was sown and the rectangles in gray represent the evaluation plots of soybean. Southern Brazil. 
Due to the occurrence of low transmissivity of solar radiation in the first crop year, we identified the need for intervention in the cultivation system. Thereby, before soybean sowing in the second crop year, pruning of the forest species was carried out in order to heighten the incidence of solar radiation inside the understory. The criteria used to prune was that $50 \%$ of the green canopy was maintained and that the branches removed below the point at which the stem of the tree had a diameter of 6-8 cm (Nicodemo et al., 2016).

To determine the productive response of soybeans, the production components were analyzed through the collection of representative plants from each experimental unit, which were previously demarcated (Figure 1). The collected plants were taken to the laboratory where the following variables were measured: plant height ( $\mathrm{PH})$, using a measuring tape graduated in $\mathrm{cm}$; number of pods per plant (NPP); and 1,000-grain weight (GW) and the number of grains per plant (NGP). To determine yield, the total grains obtained in each experimental unit were weighed and the humidity corrected to $13 \%$. The yield values, obtained in $\mathrm{g}_{\text {plant }}{ }^{-1}$, were transformed to $\mathrm{kg} \mathrm{ha}^{-1}$.

The meteorological data during the two
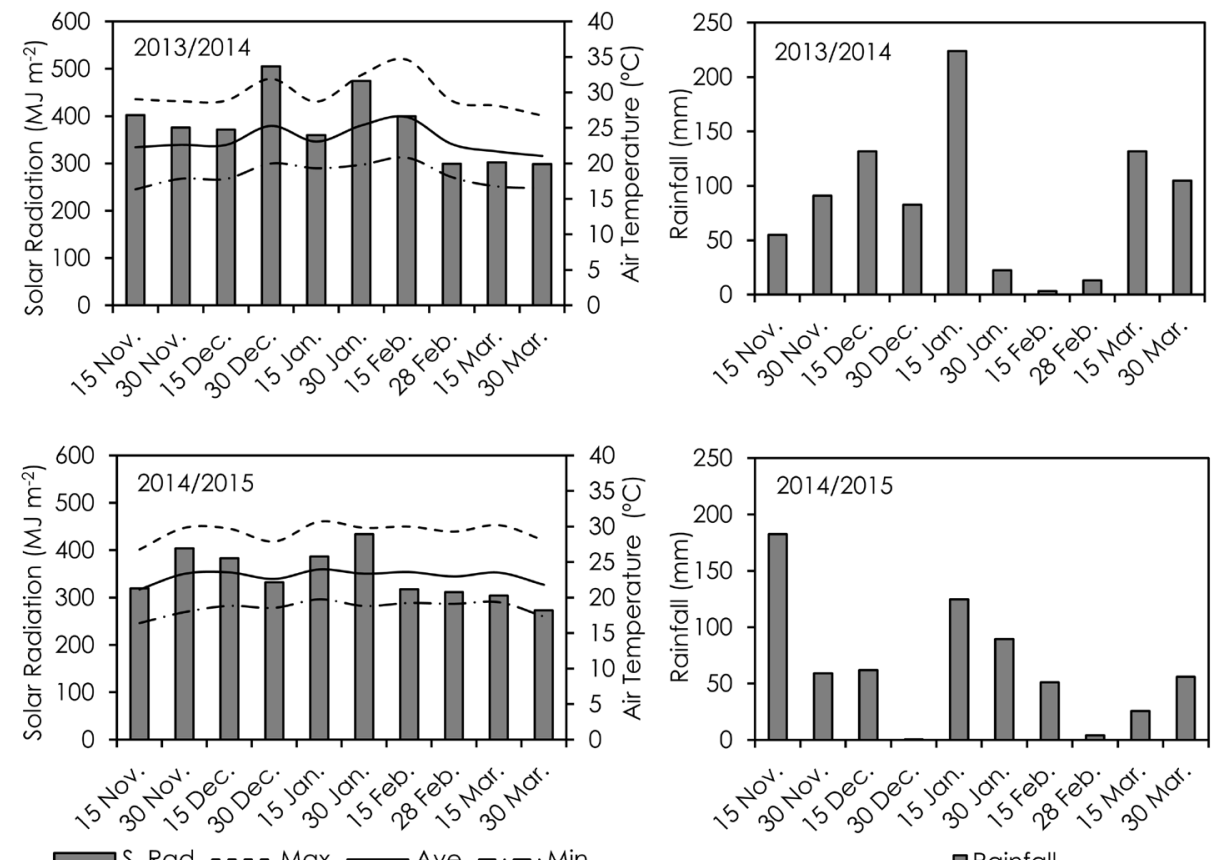

एS. Rad. - - - Max. - Ave. -. - Min Figure 2. Accumulated incident solar radiation fortnightly $\left(\mathrm{MJ} \mathrm{m}^{-2}\right)$ (S. Rad.); Air temperature $\left({ }^{\circ} \mathrm{C}\right)$, minimum
(Min.), Average (Ave.) e maximum (Max.); rainfall (mm), during the experimental period, during crop years 2013/2014 and 2014/2015. Southern Brazil. crop years were obtained from the Climatological Station of the National Meteorological Institute (INMET), linked to the Laboratory of Agroclimatology (UFSM), located about 1,500 m from the study site at the coordinates $27^{\circ} 39^{\prime} \mathrm{S}$ e $53^{\circ} 43^{\prime} \mathrm{W}$. The data were analyzed statistically with the software "Statistical Analysis System" (SAS, 2003), and the results were obtained through analysis of variance, F-test and Tukey's test $(p<0.05)$.

\section{Results and Discussion}

The incident global radiation data, air temperature (maximum, minimum and average) and rainfall during the period of the study are shown in Figure 2. Crop year 2013/2014 was characterized by air temperature in the range of $16.3^{\circ} \mathrm{C}$ to $34.6{ }^{\circ} \mathrm{C}$ and average temperature of $23.3^{\circ} \mathrm{C}$, mean solar radiation flux of 25.40 $\mathrm{MJ}$ day $^{-1}$, ranging from 5.29 $\mathrm{MJ}$ day $^{-1}$ to 39.21 MJ day ${ }^{-1}$ and an accumulated rainfall of 859.2 $\mathrm{mm}$. Additionally, crop year 2014/2015 was characterized by air temperature in the range of $16.4^{\circ} \mathrm{C}$ to $30.7^{\circ} \mathrm{C}$ and average temperature of $22.9^{\circ} \mathrm{C}$, mean solar radiation flux of $23.16 \mathrm{MJ}$ day 1, ranging from $5.5 \mathrm{MJ}$ day $^{-1}$ to $42.99 \mathrm{MJ} \mathrm{day}^{-1}$ and accumulated rainfall of $654.8 \mathrm{~mm}$.

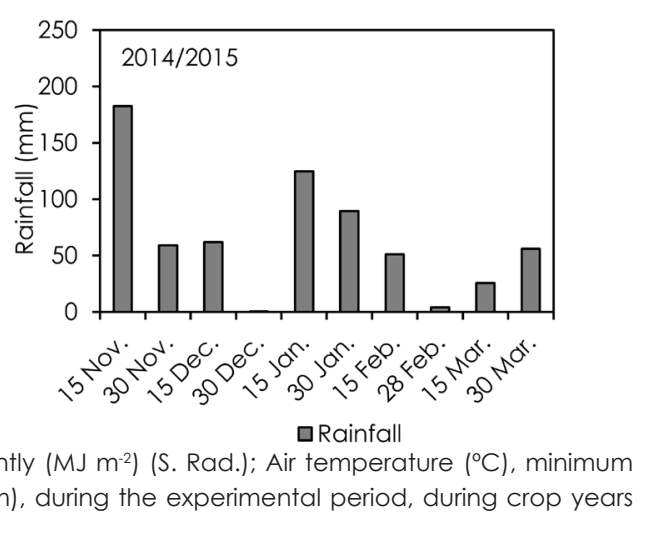


The weather conditions occurring during the productive cycle of the crop were favourable, since they met the water demand of the soybean from $450 \mathrm{~mm}$ to $850 \mathrm{~mm}$. In addition, the average air temperature also presented adequate values, set in the optimum range of $20{ }^{\circ} \mathrm{C}$ to $30{ }^{\circ} \mathrm{C}$ (Embrapa, 2013). Thereby, the productive responses of the culture are mainly related to the effect provided by the tree canopy by intercepting and reducing the availability of radiation to the soybean crop.
The amounts of solar radiation transmitted into the understory of forest species are shown in Figure 3. In the crop year 2014/2015 an increase was observed in the total transmitted solar radiation to the understory when compared to the crop year $2013 / 2014$. This result is explained by the pruning of the forest species, which promoted increases in the amount of incident solar radiation available to the understory for all species studied.

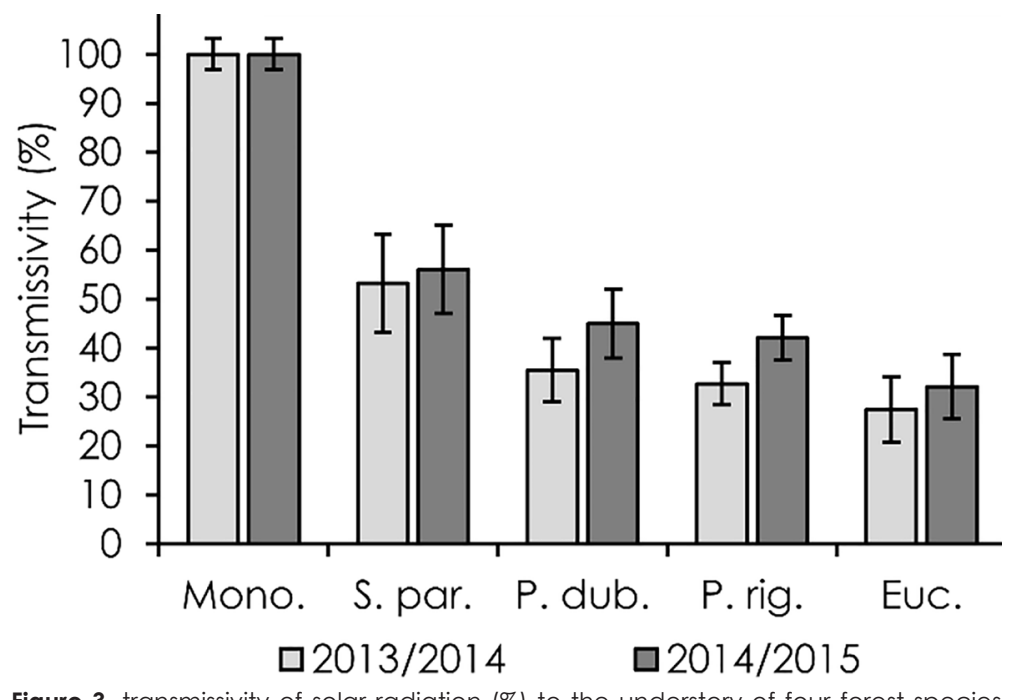

Figure 3. transmissivity of solar radiation (\%) to the understory of four forest species (S. parahyba, P. dubium, P. rigida E. urophylla $\times$ E. grandis), and monoculture during crop years $2013 / 2014$ and $2014 / 2015$. Southern Brazil. Each bars represent average values \pm SE.

When comparing the incidence of solar radiation to the understory of the different forest species, independent of the crop year or the realization of silvicultural practices, we verified that the highest transmissivity values were obtained for S. parahyba, followed by $P$. dubioum, $P$. rigida and E. urophylla $\times E$. grandis.

In the beginning of autumn/winter, $S$. parahyba, $P$. dubioum and $P$. rigida, which exhibit characteristic loss of part of their leaves, presented a lower density canopy, promoting less interception of solar radiation and consequently, greater availability of solar radiation in the understory when compared to $E$. urophylla $\times E$. grandis. In addition, this species experiences a characteristic rapid growth and expressive increase in length, diameter and canopy projection area (Wink et al., 2012), significantly increasing the interception of solar radiation by the tree canopy.

Most studies involving agroforestry systems use species of the genus Eucalyptus, such as the works conducted by Franchini et al. (2014) and Prasad et al. (2010), due to its rapid and uniform growth, adaptation to soil and climatic conditions, alternatives for use and market and high yield (Bahdwaj et al., 2016). However, in this study it was verified that the use of native species such as S. parahyba, $P$. dubioum and $P$. rigida to compose agroforestry systems favours the cultivation of species in the understory due to the greater availability of solar radiation.

Thus, the use of some native species in intercropped crops can be encouraged because of their economic potential through the supply of wood, foods and good yields, in addition to favouring the restoration of the biome (Oliveira \& Carvalhaes, 2016). Additionally, in this study it was explicit that even in intercropping with native forest species, the canopy management practices and pruning of tree components is directly related to the productive success of the 
annual crop, and therefore should be considered in the system management plan.

Considering the importance of solar radiation in the photosynthetic process and that plants grown under extreme shading conditions may present a reduction in their productive capacity (Bosi et al., 2014), the selection of forest species capable of generating a balance between the amount of solar radiation intercepted by the upper stratum of plants and the amount available to the annual crop are essential for achieving the productive success of the system (Oliveira et al., 2016), because it's the same that conditions the microclimatic characteristics generated to the understory.

Additionally, we can infer that denser plantings, where the distance between the strips of trees is only 6 meters, as in the present study, reflect negatively on the growth and development of the annual crop; thus, the use of greater spacing results in increments on the amounts of solar radiation transmitted to the lower stratum of plants (Prasad et al., 2010), enabling positive responses from the intercropping species.

In a study conducted by Oliveira et al. (2016) with the corn crop, the authors verified superior responses when the plants were placed at greater distances from the strip of trees. With these results it is possible to affirm the necessity of new studies involving other silvicultural practices, such as pruning and the use of wider spacing that allows greater availability of solar radiation and thus, benefit the crops in the consortium.

The establishment of agroforestry systems with greater distance between trees causes a smaller interception of solar radiation by the forest componente (Elli et al., 2016), resulting in smaller quantitative and qualitative changes in the solar radiation available to the understory and, thus, smaller morphophysiological modifications of the annual crop. Considering that the amount of incident solar radiation to the lower stratum of plants is dependent on the quantities intercepted by the canopy structure of the trees (Pélico Netto et al., 2015).

Thereby, silvicultural practices such as canopy driving, pruning and thinning, that raise the total amounts of incident solar radiation to the understory, as well as the use of forest species that support the intensive management to which they can be submitted, are fundamental for achieving the productive success of consortium systems. These practices directly promote reduction of interspecific and intraspecific competition present in the system.

According to the analysis of variance, there was no year $x$ species interaction for yield, making it necessary to dismember the main effects. For the variables GW, PH, NPP and NGP, a comparison was made through the Dunnett test with a $5 \%$ probability of error.

The values related to the components of soybean yield GW, PH, NPP and NGP are shown in Figure 4. For $\mathrm{PH}$ it was observed that only the cultivation in the understory of $E$. urophylla $\times E$. grandis differed from monoculture for the crop year 2013/2014 (Figure 4A); however, for the crop year 2014/2015 the monoculture showed superior $\mathrm{PH}$ in comparison to all studied forest species.

For the variable NPP and NGP, it was observed that monoculture provided superior results in relation to all forest species in both crop years (Figures $4 \mathrm{~B}$ and $4 \mathrm{C}$ ). For $\mathrm{GW}$, monoculture was superior in comparison to all forest species, except for S. parahyba in crop year 2013/2014 (Figure 4D).

Considering that soybean is a species of metabolism C3, its full growth is conditioned by high levels of solar radiation. When grown under shading conditions the plants respond with the direction of photoassimilates for the elongation of the stem and leaves, reducing the accumulation of phytomass(Taiz \& Zeiger, 2013; Bosi et al., 2014). However, when subjected to very low levels of solar radiation shading becomes an extremely limiting factor, reducing even the height of plants.

Monoculture presented the highest yield when compared to the intercropping system (Figure 5). When comparing yield for different forest species, we verified a significant difference between $P$. dubium and $E$. urophylla $x$ E. grandi with values of $479.6 \mathrm{~kg} \mathrm{ha}^{-1}$ and 272.69 $\mathrm{kg} \mathrm{ha}^{-1}$, respectively. As a result of the different management practices in the two years, the highest yields were recorded for the 2014-2015 crop year.

Plants grown under reduced solar radiation levels, like those of this study, tend to 

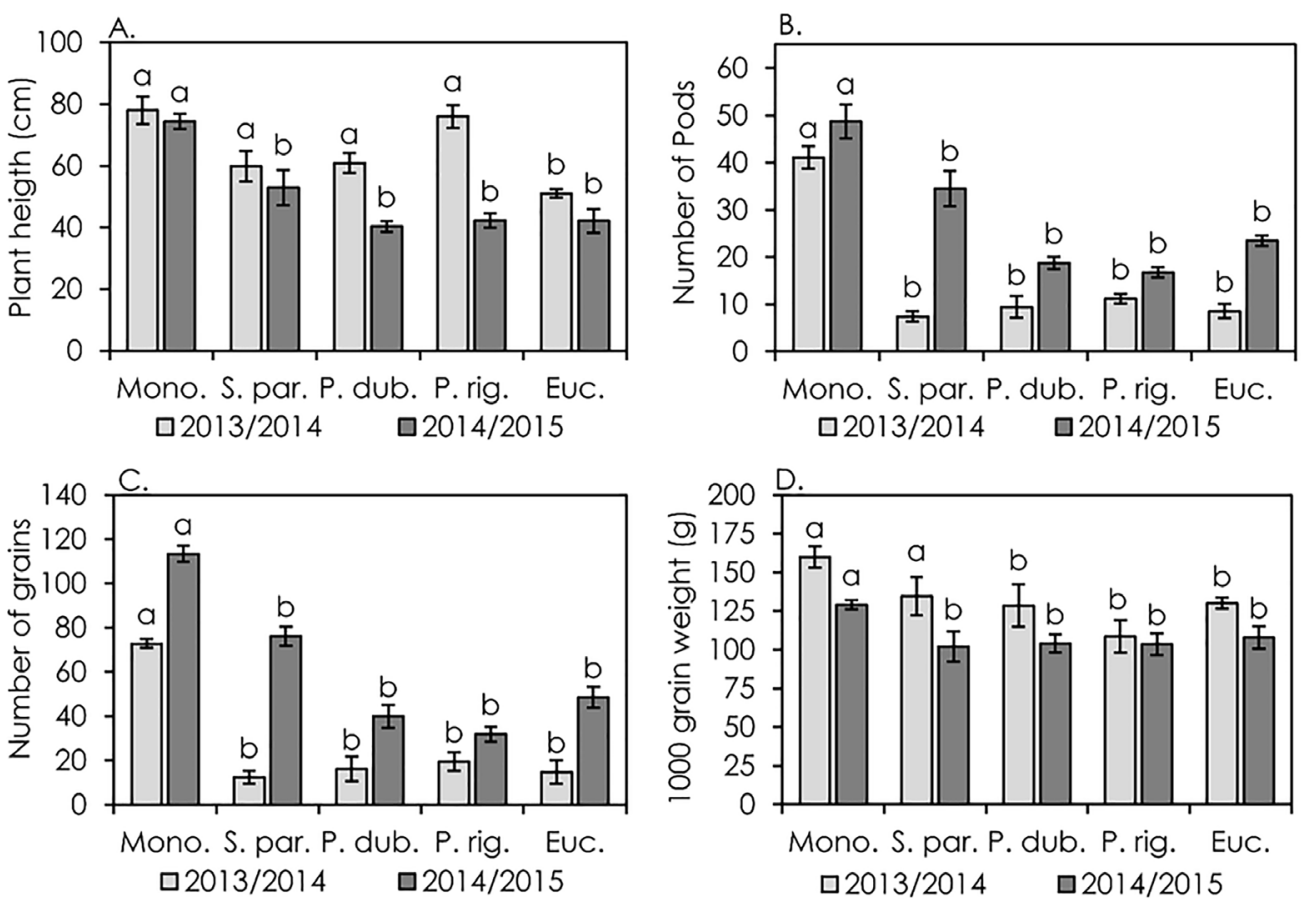

Figure 4. Plant height (A), number of pods per plant (B), number of grains per plant (C) and 1000-grain weight (D) of soybeans cultivated in agroforestry systems and monoculture, in crop years 2013/2014 and 2014/2015. Southern Brazil. *Means followed by the same letters have no significant difference by the Dunnett test $(p<0.05)$. Each bar represent saverage values \pm SE.
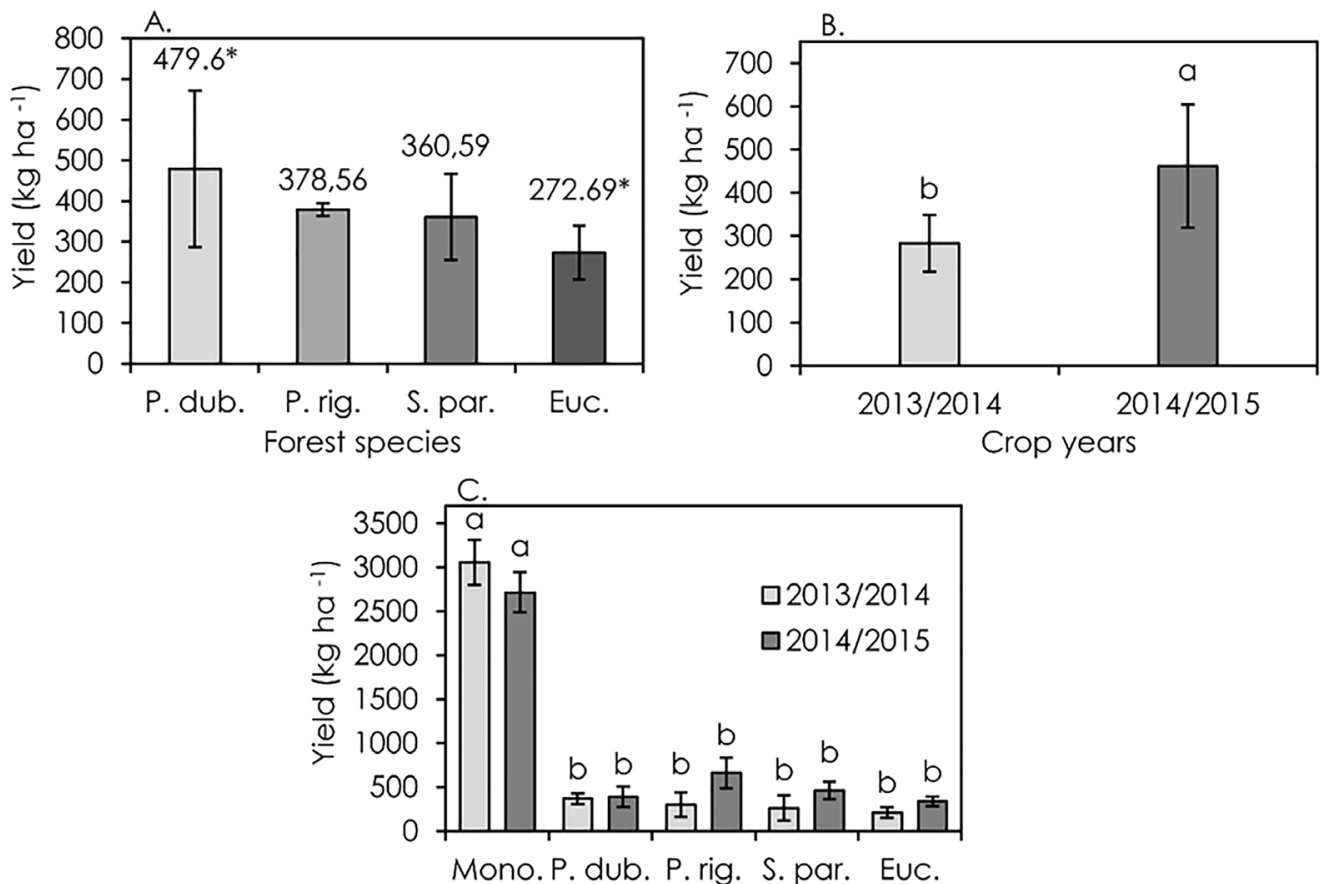

Forest species

Figure 5. Yield ( $\mathrm{kg} \mathrm{ha-1)}$ of soybeans cultivated in the understory of S. parahyba, P. dubium, P. rigida e E. urophylla $x$ E. grandis and monoculture, in 2 years of crop, 2013/2014 and 2014/2015. Southern Brazil. *Means followed by the same letters have no significant difference by the Tukey test (A and B) and by Dunnett test (C) to $5 \%$ probability of error $(p<0.05)$. Each bars represent average values \pm SE.

have lower flower retention, fewer numbers of pods and consequently lower number of grains when compared to systems that have adequate availability of solar radiation. Extreme shading conditions negatively impact the transpiratory flow of soybean plants, reducing the redistribution of nutrients and photosynthesis, increasing the abortion of flowers and thereby reducing the 
yield of the crop (Fioreze et al., 2013).

These results may be related to the quantitative and qualitative changes that the forest component exerts on the incident solar radiation to the lower stratum of plants, which conditions the growth and development of intercropped crops (Caron et al., 2012). Dense plantings and with forest species that have a higher crown density promote greater morphophysiological changes in plants, and these are due to reduced solar absorption, which reduce the conversion of $\mathrm{CO}_{2}$ into sugars (Mendes et al., 2013), thereby reducing the crop yield.

In cultivating soybean in agroforestry systems Peng et al. (2009) verified the highest values of yield in the places with the highest incidence of solar radiation; the same was observed by Righi et al. (2008). However for the bean crop, Diel et al. (2014) verified that in the first two years of establishing an agroforest with a distance of $30 \mathrm{~m}$ between the strips did not significantly impact soybean yield.

In a study developed by Franchini et al. (2014) the authors verified that the yield of soybean cultivated in the understory of
Eucalyptus muculata in the first two years of implantation did not suffer from the influence of the forest component, but in the the third and fourth years the yield decreased by $2.9 \%$ and $27 \%$, respectively, when compared to monoculture. These results were related to the lower competitive capacity of the forest species in the first two years of cultivation, where the reduced size reflected a greater availability of solar radiation to the vegetative canopy of soybean.

Additionally, it can be inferred that the yield followed the same tendency of the solar radiation transmissivity (Figure 6); since in the crop year and for the species that had a higher level of solar radiation to the understory there were better results of yield. The practice of pruning the tree component promoted a $5.48 \%$ increase in the incidence of solar radiation to the understory of S. parahyba; $26.88 \%$ for P. dubium, $28.84 \%$ for P. rigida and $17.01 \%$ for $E$. urophylla $\times$ E.grandi. This resulted in an increase in yield of $71.36 \%$ for cultivation in the understory of $S$. parahyba, $105.37 \%$ for $P$. dubium, $4.95 \%$ for P. rigida and $28.7 \%$ for E. urophylla $\times$ E.grandi, respectively.
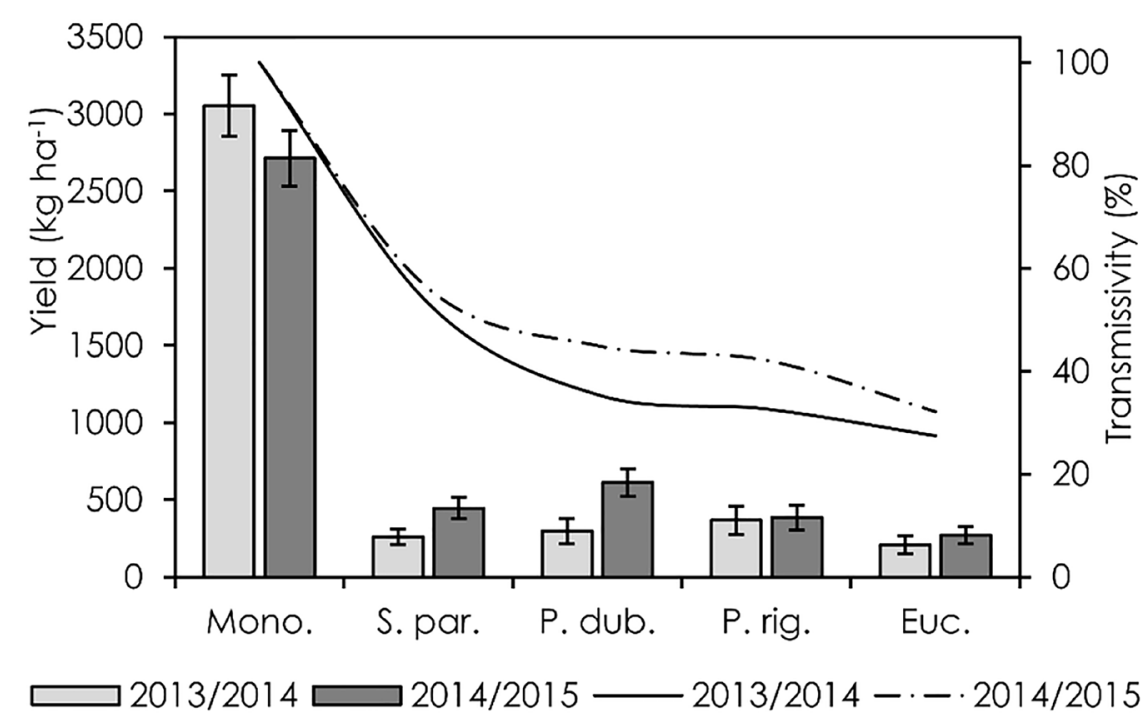

Figure 6. Transmissivity of solar radiation and yield of soybeans grown in monoculture and understory of S. parahyba, P. dubium, P. rigida and E. urophylla $\times$ E. grandis in two crop years. Continuous line represents the transmissivity during crop year 2013/2014; Dotted line indicates transmissivity during the 2014/2015 crop year. Southern Brazil. Each bar represents average values \pm SE.

During the experimental period we flux was $24.40 \mathrm{MJ} \mathrm{day}^{-1}$ and 23.1 $\mathrm{MJ}$ day $^{-1}$, for the crop years 2013/2014 and 2014/2015 respectively. observed variations in the mean solar radiation flux between the cultivation systems. For In the understory of $S$. parahyba we observed a monoculture the verified mean solar radiation mean solar radiation flux of $13.50 \mathrm{MJ}^{\text {day }}{ }^{-1}$ and 
$12.98 \mathrm{MJ} \mathrm{day}^{-1}$ for the crop years 2013/14 and $2014 / 15$. Below the canopy of $P$. dubium trees we observed a mean flux of $9.00 \mathrm{MJ}^{\text {day }}{ }^{-1}$ and 10,412 MJ day ${ }^{-1}$ for the crop years $2013 / 14$ and 2014/15. In the understory of $P$. rigida we observed a mean flux of $8.30 \mathrm{MJ} \mathrm{day}^{-1}$ and $9.74 \mathrm{MJ} \mathrm{day}^{-1}$ for the crop years $2013 / 14$ and $2014 / 15$. For the understory of E. urophylla $x$ E.grandis we observed a mean flux of 6,973 $\mathrm{MJ}_{\text {day }}{ }^{-1}$ and $7.44 \mathrm{MJ}$ day $^{-1}$ for the crop years 2013/14 and 2014/15 respectively.

Considering the mean values of solar radiation incident to the understory of the forest species it has been verified that the average solar radiation flux is below or very close to the trophic limit for the soybean crop, which according to Fagan et al. (2010) is $8.4 \mathrm{MJ}^{\text {day }}{ }^{-1}$. Therefore, these values may have induced the low yield of the culture, especially in the first crop year.

Soybean crop presents a high energy cost for the production of grains, because these are predominantly composed of proteins. Proteins require a high amount of energy for the conversion of photoassimilates compared to other photosynthetic products, as carbohydrates, primary product of photosynthesis and a major components of the grains of numerous crops (Taiz \& Zeiguer 2013). Given the high energy demand of soybean for the production of grains, and the reduced income ceilings obtained in this study, we inferred that levels below $50 \%$ of transmissivity drastically compromise soybean yield.

Given this, management practices, such as pruning and the removal of some trees from the interior of the system, to minimize the negative impacts generated by the forest component on the growth and development of the annual crop are indispensable (Nicodemo et al., 2016). Silvicultural practices such as pruning and removal of trees from the system must be considered in order to obtain the productive success of the crop in a consortium, since they directly condition the microclimatic characteristics generated to the understory.

Studies of productive characteristics and the dynamics of solar radiation in agroforestry systems are less widespread. Thus, the information generated in this study is relevant to providing information to assist farmers in planning the selection of forest species to be used in the planting of an agroforest. It also demonstrates the need to develop future studies toidentify the arrangement of plants that favour both agricultural production and forest production, and define the criteria for the management of forest species.

The study sought to provide sustainable production alternatives for farmers, with the purpose of promoting the diversification of production on rural property and maintaining the preservation of existing agroecosystems. Thereby, the use of agroforestry systems is an alternative for the production of areas adjacent to water courses and remnants of native forest. According to Law12,651/2012, which constitutes the Brazilian forest code, farmers can make use of agroforestry systems in their permanent preservation areas and legal reserves, provided that such systems are subject to a sustainable management plan.

\section{Conclusions}

The dynamics of solar radiation and soybean yield varied according to the forest species used to compose the agroforestry system: S. parayba, $P$. dubium and $P$. rigina present the potential to compose the agroforestry system, due to their canopy structure, leaf architecture and leaf loss during autumn, which provided greater availability of solar radiation in the understory.

Interception of solar radiation by the forest component of higher than $50 \%$ significantly reduces the yield of soybean grown in agroforestry systems, highlighting the necessity of silvicultural practices that promote the increase of available solar radiation to the understory.

\section{Acknowledgements}

The authors wish to acknowledge the National Council for Scientific and Technological Development (CNPq-Brazil) for the productivity scholarship awarded to the co-author Braulio $\mathrm{O}$. Caron and the Coordination for the Imptovement of Higher Education Personnel (Capes-Brazil) for their financial support of the author Jaqueline sgarbossa.

\section{References}

Alvares, C.A., Stape, J.L., Sentelhas, P.C., 
Gonçalves, J.L.M., Sparovek, G. 2013. Köppen's climate classification map for Brasil. Meteorologische Zeitschritf 22: 711-728.

Behling, A., Sanquetta, D.R., Dalla Corte, A.P., Netto, S.P., Rodrigues, A.L., Caron, B.O., Simon, A.A. 2016. Tracking leaf area index and coefficient of light extinction over the harvesting cycle of black wattle. Journal of Forestry Research 27: 1211-1217.

Bosi, C., Pezzopane, J.R.M., Sentelhas, P.C., Santos, P.M., Nicodemo, M.L.F. 2014. Produtividade e características biométricas do capim-braquiária em sistema silvipastoril. Pesquisa Agropecuária Brasileira 49: 449-456.

Brooker, R.W., Bennett, A.E., Cong, W.F., Daniell, T.J., George, T.S., Hallett, P.D., Hawes, C., Lannetta, P.P.M., Jones, H.G., Karley, A.J., Li, L., McKenzie, B.M., Pakeman, R.J., Paterson, E., Schöb, C., Shen, J., Squire, G., Watson, C.A., Zhang, C., Zhang, F., Zhang, J., White, P.J. 2014. Improving intercropping: a synthesis of research in agronomy, plant physiology and ecology. New Phytologist 206: 107-117.

Caron, B.O., Souza, V.Q., Costa, E.C., Eloy, E. Behling, A., Trevisan, R. 2012. Interceptação da radiação luminosa pelo dossel de espécies florestais e sua relação com o manejo das plantas daninhas. Ciência Rural 42: 75-82.

Diel, D., Behling, M., Neto, A.L.F., Isemnhagen, E.C.C. Distribuição horizontal e vertical de fósforo em sistemas de cultivos exclusivos de soja e de integração lavoura-pecuária-floresta. 2014. Pesquisa Agropecuária Brasileira 49: 639-647.

Elli, E.F., Caron, B.O., Eloy, E., Behling, A., Souza, V.Q., Schwerz, F. 2016. Productive, morphological and qualitive characteristics of sugarcane in the understory tree species in agroforestry systems. African Journal of Agricultural Research 11: 15761584.

Embrapa - Empresa Brasileira de Pesquisa Agropecuária. Tecnologias de Produção de Soja-Região Central do Brasil 2014. 2013. https:// ainfo.cnptia.embrapa.br/digital/bitstream/ item/95489/1/SP-16-online.pdf <Acesso em 17 Mar. 2017>

Fagan, E.B., Neto, D.D., Vivian, R., Franco, R.B., Yeda, M.P., Massignam, L.F., Oliveira, R.F., Martinz, K.V. 2010. Efeito da aplicação de piraclostrobina na taa fotossintética, respiração, atividade da enzima nitrato redutase e produtividade de grãos de soja. Bragantia 69: 771-777.

Fioreze, S.L., Rodrigues, J.D., Carneiro, J.P.C., Silva, A.A., Lima, M.B. 2013. Fisiologia e produção da soja tratada com cinetina e cálcio sob déficit hídrico e sombreamento. Pesquisa Agropecuária
Brasileira 48: 1432-1439.

Franchini, J.C., Junior, A.A.B., Sichieri, F.R., Debias, $\mathrm{H}$., Conte, O. 2014. Yield of soybean, pasture and wood in integrated crop-livetock-forest system in Northwestern Paraná state, Brasil. Revista Ciência Agronômica 45: 1006-1013.

Godfray, H.C.J., Beddington, J.R., Crute, I.R., Haddad, L., Lawrence, D., Muir, J.F., Pretty, J., Robinson, S., Thomas, S.M., Toulmin, C. 2010. Food security: the challenge of feeding 9 billion people. Science 327: 812-818.

Mendes, M.M.S., Lacerda, C.F., Cavalcante, A.C.R., Fernandes, F.E.P., Oliveira, T.S. 2013. Desenvolvimento de milho sob influência de árvores de pau-brando em sistema agrossilvipastoril. Pesquisa Agropecuária Brasileira 48: 1342-1350.

Müller, M.D., Paciullo, D.S.C., Martins, C.E., Rocha, W.S.D., Castro, C.R.T. 2014. Desenvolvimento vegetativo de pinhão-manso em diferentes arranjos de plantio em sistemas agrossilvipastoris. Pesquisa agropecuária brasileira 49: 506-514.

Nicodemo, M.L.F., Castiglioni, P.P., Pezzopane, J.R.M., Tholon, P., Carpanezzi, A.A. 2016. Reducing competition in agroforestry by pruning native trees. Revista Árvore 40: 509-518.

Oliveira, R.E., Carvalhaes, M.A. 2016. Agroforestry as a tool for restoration in atlantic forest: can we find multi-purpose species?. Oecologia Australis 20: 425-435.

Oliveira, V.R., Silva, P.S.L., Paiva, H.N., Pontes, F.S.T., Antonio, R.P. 2016. Growth of arboreal leguminous plants and maize yield in agroforestry systems. Revista Árvore 40: 679-688.

Pélico Netto, S.P., Sanquetta, C.R., Caron, B.O., Behling, A., Simon, A.A., Corte, A.P.D., Bamberg, R. 2015. Ground level photosynthetically active radiation dynamics in stands of Acacia mearnsii De Wild. Annals of the Brazilian Academy of Sciences 87: 1833-1845.

Peng, X., Zhang, Y., Cai, J., Jiang, Z., Zhang, S. 2009. Photosynthesis, growth and yield of soybean and maize in a tree-based agroforestry intercropping system on the Loess Plateau. Agroforestry Systms 76: $569-577$.

Prasad, J.V.N., Korwar, G.R., Rao, K.V., Mandal, U.K., Rao, C.A.R., Rao, G.R., Ramajrishna, Y.S., Venkateswarlu, B., Rao, S.N., Kulkarni, H.D., Rao, M.R. 2010. Tree row spacing affectedagronomic and economic performance of Eucalyptusbased agroforestry in Andhra Pradesh, Southern India. Agroforestry Sistems 78: 253-267.

Righi, C.A., Bernardes, M.S. 2008. Disponibilidade de energia radiante em um sistema agroflorestal 
com seringueiras produtividade do feijoeiro. Bragantia 67: 533-540.

Salton, J.C., Mercante, F.M., Tomazi, M., Zanatta, J.A., Concenço, G., Silva, W.M., Retore, M. 2012. Integrated crop-livestorck system in tropical Brasil: Toward a sustainable production system. Agriculture, Ecosystems and Environment 190: 7079.

SAS Learning Edition. Getting started with the SAS Learning Edition. Cary, 200p, 2003.

Taiz, L., Zeiger,E. 2013. Fisiologia Vegetal. 5.ed. Artmed, Porto Alegre, Brasil. 918p.

Tracy, B.F., Zhang, Y. 2008. Soil compaction, corn yield response, and soil nutrient pool dynamics within and integrated crop-livestock system in Illinois. Crop Science 48: 1211-1218.

Wink, C., Monteiro, J.S., Reinert, D.J., Liberalesso, E. 2012. Parâmetros da copa e a sua relação com o diâmetro e altura das árvores de eucalipto em diferentes idades. Scientia Forestalis 40: 057-067. 